\title{
Examination of Correlations Between Several Biochemical Components and Powdery Mildew Resistance of Flax Cultivars
}

\author{
Aly A. Aly ${ }^{1}$, Mahmoud T. M. Mansour ${ }^{1}$, Heba I. Mohamed ${ }^{2}$ and Kamel A. Abd-Elsalam ${ }^{1 *}$ \\ ${ }^{\text {I} P l a n t ~ P a t h o l o g y ~ R e s e a r c h ~ I n s t i t u t e, ~ A g r i c u l t u r a l ~ R e s e a r c h ~ C e n t e r, ~ G i z a, ~ E g y p t ~}$ \\ ${ }^{2}$ Department of Biological and Geological Sciences, Faculty of Education, Ain Shams University, Cairo, Egypt \\ (Received on February 8, 2012; Revised on April 29, 2012; Accepted on May 2, 2012)
}

A field trial was conducted in $2009 / 2010$ and 2010/2011 growing seasons at Giza Agricultural Research Station to examine correlations between some biochemical componets and powdery mildews $\left(\mathrm{PM}_{\mathrm{s}}\right)$ resistance in flax cultivars. Nine flax cultivars could be divided into five distinct groups, i.e., highly susceptible (Cortland and C.I. 2008), moderately susceptible (Giza 7, and Marshall), moderately resistant (Cass), resistant (Koto, Dakota and Wilden), and highly resistant (Ottowa 770B). The cultivars showed considerable variation in PM severity ranged from 8.05 on Ottowa $770 \mathrm{~B}$ to $97.02 \%$ on Cortland. Total soluble proteins, total phenols, antioxidant enzymes (peroxidase and polyphenoloxidase), ascorbic acid, tocopherol, and malondialdehyde (MDA), were determined in uninfected leaves of the tested cultivars. Pearson's correlation coefficient was calculated to measure the degree of association between PM severity and each component. All components showed significant $(P$ $<0.05)$ or highly significant $(P<0.01)$ negative correlation with PM severity except MDA, which showed positive correlation $(P<0.01)$. Linear regression analysis was used to evaluate the causal relationship between the biochemical components (independent variables) and PM severity (dependent variable). Coefficient of determination $\left(R^{2}\right)$ values of the generated models ranged from 48.76 to $77.15 \%$. Tocopherol, MDA, and proteins were the most important contributors to the total variation in PM severity as the $\mathbf{R}^{2}$ values of their models were $71.78,75.28$, and $77.15 \%$, respectively. The results of the present study suggest that tocopherol, MDA, and proteins in uninfected leaves can be used as biochemical markers to predict PM resistance in flax.

Keywords : biochemical markers, disease severity, Linum usitatissimum, Oidium lini

Flax (Linum usitatissimum L.) is considered the most important bast fiber crop in Egypt, it ranks second after

\footnotetext{
*Corresponding author.

Phone) 002-35724893, FAX) 002-35723146

E-mail) abd-elsalam.k.a@post.com
}

cotton (seedy fiber) regarding economic importance and production (Aly et al., 1994).

Powdery mildew (PM) caused by Oidium lini Škoric is currently the most common, conspicuous, widespread, and easily recognized foliar disease of flax in Egypt (Aly et al., 1994). Over the last two decades, the importance of this disease has increased probably due to the appearance and rapid distribution of new races capable of attacking the previously resistant cultivars (Aly et al., 1994).

In India, Pandy and Misra (1993) reported that as the disease increased, yield losses increased ranging from 11.8 to $38.9 \%$, yield losses were greater when the disease appears earlier in the season. Accurate assessment of losses due to the disease in Egypt has not been reported. However, Aly et al. (1994) found significant negative correlations between disease intensity ratings and agronomic traits (yield and yield components).

Currently, resistance is not available in the commercially grown flax cultivars in Egypt (Aly at al., 2002). Therefore, in years when environmental conditions favor the development of the disease, foliar application of fungicides has become the only commercially available management practice for the disease control (Aly et al., 1994).

Extensive genetic variation for PM resistance has been identified in some flax populations. For example, Prasad et al. (1988) evaluated 2822 linseed varieties for rust and PM resistance. The germplasm was classified depending on the percentage of leaf area infected/plant. Only 24 lines were free from both rust and PM, and 17 showed multiple resistances (1-10\% leaf area infected/plant). In addition, 38 genotypes were free from rust and resistant to PM, and three were free from PM and resistant to rust. Basandrai et al. (1994) evaluated 200 indigenous and exotic flax genotypes for resistance to PM under field conditions. Twentyfour genotypes were free from infection, and 12 genotypes were resistant to PM and also possessed desirable plant height for fiber flax. Mahto et al. (1995) found a significant variability among 26 flax genotypes in resistance to PM. Eleven had above average stability and seven of these had high yields. Of 43 flax introductions evaluated in a two- 
year outdoor pot experiment, Mansour et al. (2003) found that only three introductions showed satisfactory levels of resistance in both years. Some of the other introductions were resistant in only one year, which indicated that their performance lacked stability.

It has been suggested that a variety of substances contained in plant cells are involved in resistance or susceptibility to infection by pathogens. Among these are proteins (Strange, 2003), phenols (Agrios, 2005), ascorbic acid (Vidyasekaran, 2008), tocopherol (Castle and Day, 1984), peroxidase, polyphenoloxidase (Agrios, 2005), and malondialdehyde as indicator of lipid peroxidation (Göbel et al., 2003).

No information about the biochemical basis of resistance or susceptibility of flax to PM seems to be available yet. Therefore, the objective of the present study was to investigate how the previously mentioned biochemical components affect resistance of susceptibility of flax to PM in different host-pathogen interaction.

\section{Materials and Methods}

Reactions of flax cultivars to PM. A field trial was conducted in 2009/2010 and 2010/2011 growing seasons at Giza Agricultural Research Station to evaluate PM severity on nine flax cultivars. The experiment consisted of a randomized complete block design of three replications (blocks). Plots were $2 \times 3\left(6 \mathrm{~m}^{2}\right)$ and consisted of ten rows spaced $20 \mathrm{~cm}$ apart. Seeds of each cultivar were sown by hand at a rate of $70 \mathrm{~g} /$ plot. Planting date was the first week of December. Disease severity was rated visually in the last week of April (Nutter et al., 1991).

Assay of Total phenols. Soluble phenols in fresh samples were extracted according to Dihazi et al. (2003). A known weight of fresh samples was selected and extracted with $80 \%$ cold methanol (v/v) for three times at $90^{\circ} \mathrm{C}$. The combined extract were collected and filtered through Whatman No.1 filter paper. After filtration, the filtrate was made up to a known volume with cold methanol.

A known volume of the extract $(0.5 \mathrm{ml}$ was added to 0.5 $\mathrm{ml}$ folin-Cicalteu reagent and shacked well. The mixture was allowed to stand for $3 \mathrm{~min}$. one $\mathrm{ml}$ of saturated sodium carbonate solution $\left(25 \mathrm{~g} \mathrm{Na}_{2} \mathrm{CO}_{3}\right.$ were dissolved in $1000 \mathrm{ml}$ distilled water at $70-80^{\circ} \mathrm{C}$ and cooled down and filtered) was added to the mixture and shaked well. The mixture was allowed to stand for $60 \mathrm{~min}$. the optical density was measured at $725 \mathrm{~nm}$ UV-Vis spectrophotometer. The quantity of total phenolic compounds was calculated according to the standard curve of gallic acid $(99.5 \%)$ and expressed as $\mathrm{mg} / 100 \mathrm{~g}$ fresh weight.
Assay of polyphenoloxidase activity. Polyphenoloxidase (EC 1.14.18.1) was assayed following the method described by Kar and Mishra (1976) with little modification, $5 \mathrm{ml}$ of the assay mixture contained $125 \mu \mathrm{M}$ of phosphate buffer (pH 6.8), $100 \mu \mathrm{M}$ pyrogallol and $1 \mathrm{ml}$ of crude enzyme extract. After incubation at $25^{\circ} \mathrm{C}$ for $5 \mathrm{~min}$, the reaction was stopped with the addition of $1 \mathrm{ml}$ of $10 \% \mathrm{H}_{2} \mathrm{SO}_{4}$ the colour intensity was read at $430 \mathrm{~nm}$, and the enzyme activity was expressed as enzyme activity/gram fresh weight/h.

Extraction of enzymes and total soluble protein. Two grams of fresh sample were homogenized either in cold phosphate buffer $(0.05 \mathrm{M}$ at $\mathrm{pH} 6.5)$. The homogenate was centrifuged at $1,000 \mathrm{rpm}$ for 10 minutes. The pigments were removed from the supernatant by adsorbing on activated charcoal and filtered. The filtrate was completed to a known volume and used to determine enzymes and total soluble protein.

Assay of peroxidase activity. Peroxidase (EC 1.11.1.7) was assayed following the method of Kar and Mishra (1976) with slight modification. Five $\mathrm{ml}$ of the assay mixture contained $300 \mu \mathrm{M}$ of phpsphate buffer (pH 6.8), 50 $\mu \mathrm{M}$ catechol, $50 \mu \mathrm{M} \mathrm{H}_{2} \mathrm{O}_{2}$ and $1 \mathrm{ml}$ of crude enzyme extract was prepared. After incubation at $25^{\circ} \mathrm{C}$ for $5 \mathrm{~min}$, the reaction was stopped with the addition of $1 \mathrm{ml}$ of $10 \%$ $\mathrm{H}_{2} \mathrm{SO}_{4}$. The colour was read at $430 \mathrm{~nm}$ and the enzyme activity was expressed as enzyme activity/gram fresh weight/h.

Estimation of total soluble protein. Alkaline tartarate reagent $20 \mathrm{~g}$ sodium carbonate and $0.5 \mathrm{~g}$ tartarate were dissolved in liter of $0.1 \mathrm{~N} \mathrm{NaOH}$. Ten $\mu \mathrm{l}$ of the portein sample was added to $5 \mathrm{ml}$ of the working alkaline copper reagent, and was allowed to stand for $15 \mathrm{~min}$. at room temperature. The dilution folin reagent $(0.5 \mathrm{ml})$ was then mixed immediately with the mixture; and allowed to stand $30 \mathrm{~min}$. at room temperature the color intensity of samples was measured at $750 \mathrm{~nm}$. The total soluble protein content in the superntant was detrmined according to Lowry et al. (1951) the quantity of total soluble protein was calculated according to the standard curve of Bovine Serum Albumin and expressed as $\mathrm{mg} / \mathrm{m}$ fresh weight.

Ascorbic acid assay. A known weight $(2-5 \mathrm{~g})$ of fresh samples was ground in $6 \%$ trichloroacetic acid (TCA) and the extract filtered throught filter paper and centrifuged at $1000 \mathrm{rpm}$ for $20 \mathrm{~min}$. The filtrate was made up to $10 \mathrm{ml}$ with TCA. Ascobic acid was determind as described by Mukherjee and Choudhuri (1983). Four $\mathrm{ml}$ of the extract was mixed with $2 \mathrm{ml}$ of $2 \%$ dinitrophenyl hydrazine (in 
acidic medium) follwed by the addition of drop of $10 \%$ thiourea (in 70\% ethanol). The mixture was boiled for 15 $\min$ in a water bath and after cooling to room temperature, $5 \mathrm{ml}$ of $80 \%(\mathrm{v} / \mathrm{v}) \mathrm{H}_{2} \mathrm{SO}_{4}$ was added to the mixture at $0^{\circ} \mathrm{C}$ (in an ice bath) the absorbance was recorded at $530 \mathrm{~nm}$ using spectrophotometer. The cocentration of ascorbic aid was calcilated from a standrad curve plotted with known concentration of ascorbic acid and expressed as $\mathrm{mg} / \mathrm{g}$ fresh weight.

$\alpha$-Tocopherol assay. $\alpha$-tocopherol activity was assayed as described by Philip et al. (1954). Five hundred mg of fresh tissue was homogenized with $10 \mathrm{ml}$ of a mixture of petroleum ether and ethanol $(2: 1.6 \mathrm{v} / \mathrm{v})$ and the extract was centrifuged at 10,000 rpm for $20 \mathrm{~min}$ and the supernatant was used for estimation of $\alpha$-tocopherol. One $\mathrm{ml}$ of extract, $0.2 \mathrm{ml}$ of 2\% 2.2-dipyridyl in ethanol was added and mixed thoroughly and kept in the dark for $5 \mathrm{~min}$. the resulting red colour was diluted with $4 \mathrm{ml}$ of distiled water and mixed well. The resulting colour in the aqueous layer was measured at $520 \mathrm{~nm}$ the $\alpha$-tocopherol content was calculated using a standard graph made with a known amount of $\alpha$ tocopherol. The results were expressed in $\mu \mathrm{g} / \mathrm{g}$ fresh weight.

Assay of malondialdehyde (MDA) content. The content of MDA was measured according to the method of Heath and Packer (1968). Fresh samples $(0.5 \mathrm{~g})$ were homogenized in $10 \mathrm{~mL}$ of $6 \%$ trichloroacetic acid and then centrifuged at $10,000 \mathrm{rpm}$ for $15 \mathrm{~min}$. The supernatant $(1 \mathrm{~mL})$ was mixed with $4 \mathrm{ml}$ of $0.5 \%$ thiobarbitric acid and then heated at $95^{\circ} \mathrm{C}$ for $30 \mathrm{~min}$. The non-specific absorbance at $600 \mathrm{~nm}$ was subtracted from the $532 \mathrm{~nm}$ absorbance. The absorbance coefficient of malondialdehyde was calculated by using the extinction coefficient of 155 $\mathrm{m} / \mathrm{M} / \mathrm{cm}$ and expressed as a total MDA nmol/g fresh weight.

Statistical analysis. The experimental design of the field trials and the laboratory tests was randomized complete block with three replicates (blocks). Analysis of variance (ANOVA) of the data was performed with MSTAT-C. Duncan's multiple range test was used to compare cultivar means. Linear correlation coefficient (r) was calculated to evaluate the degree of association between levels or activities of biochemical components and PM severity ratings on the tested cultivars. Linear regression analysis was used to evaluate the causal relationship between the biochemical components (independent variables) and PM severity (dependent variable). Correlation and regression analysis was performed with a computerized program (SPSS Version 13).

\section{Results and Discussion}

Environmental conditions in 2009/2010 and 2010/2011 growing seasons were favorable for epiphytotic spread of the disease. This was apparent as these environmental conditions resulted in $97.02 \%$ PM severity on cultivar Cortland, which is known as highly susceptible (A.A. Aly, personal observations). In general, the tested cultivars could be divided into five distinct groups, i.e. highly susceptible (Cortland and C.I. 2008), moderately susceptible (Giza 7, and Marshall), moderately resistant (Cass), resistant (Koto, Dakota, and Wilden), and highly resistant (Ottowa 770 B). The cultivars showed considerable variation in PM severity ranged from 8.05 on Ottowa $770 \mathrm{~B}$ to 97.02\% on Cortland (Table 1).

Levels and activities of seven biochemical components were determined in leaves of nine flax cultivars varying in PM severity (Table 2). The levels and activities of the tested components varied with the cultivar. However, MDA was the only component, which did not show significant differences between cultivars.

Levels and activities of all the tested components (Table 3) showed highly significant and positive correlations with each other ( $\mathrm{r}$ value ranged from 0.892 to $0.983, P<0.01$ ). MDA was a notable exception because it showed highly significant and negative correlations with all the components ( $\mathrm{r}$ value ranged from -0.853 to $-0.971, P<0.01$ ).

In the present study, associations among the tested bio-

Table 1. Powdery mildew severity ratings on nine flax cultivars and their disease categories under field conditions in Giza in 2009/ 2010 and 2010/2011 growing seasons

\begin{tabular}{lcc}
\hline \hline Cultivar & Disease severity $^{\mathrm{a}}(\%)$ & Disease category $^{\mathrm{b}}$ \\
\hline Cortland & $97.02 \mathrm{~A}$ & $\mathrm{HS}$ \\
C.I. 2008 & $95.86 \mathrm{~A}$ & $\mathrm{HS}$ \\
Giza 7 & $70.36 \mathrm{BC}$ & $\mathrm{MS}$ \\
Marshall & $64.72 \mathrm{C}$ & $\mathrm{MS}$ \\
Cass & $48.51 \mathrm{D}$ & $\mathrm{MR}$ \\
Koto & $24.00 \mathrm{E}$ & $\mathrm{R}$ \\
Dakota & $21.67 \mathrm{E}$ & $\mathrm{R}$ \\
Wilden & $18.29 \mathrm{E}$ & $\mathrm{R}$ \\
Ottowa $770 \mathrm{~B}$ & $8.05 \mathrm{~F}$ & $\mathrm{HR}$ \\
\hline
\end{tabular}

\footnotetext{
${ }^{\mathrm{a}}$ Disease severity is the percentage of infected leaves/plant in a random sample of 10 plants/plot. Each value is the mean of two growing seasons and each season included three replicates. Percentage data were transformed into arcsine angles before carrying out the analysis of variance to normalize data and stabilize variance throughout the data range. Means followed by the same letter are not significantly different $(P<0.05)$ according to Duncan's multiple range test.

${ }^{\mathrm{b}}$ Disease categories are highly susceptible (HS), moderately susceptible (MS), moderately resistance (MR), resistant (R), and highly resistant (HR).
} 
Table 2. Determination of levels and activities of some biochemical components in uninfected leaves of nine flax cultivars

\begin{tabular}{|c|c|c|c|c|c|c|c|}
\hline \multirow[b]{2}{*}{ Cultivar } & \multicolumn{7}{|c|}{ Component } \\
\hline & $\begin{array}{l}\text { Total protein } \\
\text { (mg/g fresh } \\
\text { weight) }\end{array}$ & $\begin{array}{l}\text { Phenols } \\
\text { (mg/g fresh } \\
\text { weight) }\end{array}$ & $\begin{array}{l}\text { Ascorbic acid } \\
\text { ( } \mu \mathrm{g} / \mathrm{g} \text { fresh } \\
\text { weight) }\end{array}$ & $\begin{array}{l}\text { Tocopherol } \\
\text { ( } \mu \mathrm{g} / \mathrm{g} \text { fresh } \\
\text { weight) }\end{array}$ & $\begin{array}{c}\text { Malondialdehyde } \\
\text { (MDA) } \\
\text { (n mol/g/fresh weight) }\end{array}$ & $\begin{array}{l}\text { Peroxidase } \\
\text { (activity/h/g } \\
\text { fresh weight) }\end{array}$ & $\begin{array}{l}\text { Polyphenoloxidase } \\
\text { (activity/h/g } \\
\text { fresh weight) }\end{array}$ \\
\hline $\begin{array}{l}\text { Ottowa } \\
770 \mathrm{~B}\end{array}$ & $62.22^{\mathrm{a}} \mathrm{A}$ & $125.30 \mathrm{~A}$ & $18.54 \mathrm{AB}$ & $63.16 \mathrm{~A}$ & $10.65 \mathrm{~A}$ & $32.77 \mathrm{AB}$ & $17.02 \mathrm{~A}$ \\
\hline Dakota & $61.05 \mathrm{AB}$ & $128.40 \mathrm{~A}$ & $19.72 \mathrm{~A}$ & $57.69 \mathrm{AB}$ & $13.36 \mathrm{~A}$ & $37.68 \mathrm{~A}$ & $17.68 \mathrm{~A}$ \\
\hline Cass & $57.96 \mathrm{~A}-\mathrm{C}$ & $109.90 \mathrm{AB}$ & 14.59 A-E & $53.93 \mathrm{BC}$ & $13.16 \mathrm{~A}$ & $31.05 \mathrm{~A}-\mathrm{C}$ & $12.52 \mathrm{BC}$ \\
\hline Wilden & 54.90 B-D & $93.53 \mathrm{~A}-\mathrm{C}$ & $12.55 \mathrm{C}-\mathrm{E}$ & $50.27 \mathrm{CD}$ & $13.93 \mathrm{~A}$ & 27.10 A-E & $9.50 \mathrm{CD}$ \\
\hline Koto & $53.78 \mathrm{CD}$ & 74.26 C-E & 9.55 E-G & $44.24 \mathrm{D}-\mathrm{F}$ & $14.97 \mathrm{~A}$ & 25.37 A-E & $9.19 \mathrm{CD}$ \\
\hline Marshall & $47.43 \mathrm{E}$ & 89.39 B-D & $11.67 \mathrm{D}-\mathrm{F}$ & $41.45 \mathrm{E}-\mathrm{G}$ & $16.37 \mathrm{~A}$ & 24.75 B-E & $9.30 \mathrm{CD}$ \\
\hline Giza 7 & $50.16 \mathrm{DE}$ & 72.96 C-E & $9.41 \mathrm{E}-\mathrm{G}$ & 47.76 C-E & $15.42 \mathrm{~A}$ & 26.07 A-E & $9.43 \mathrm{CD}$ \\
\hline Cortland & $46.83 \mathrm{E}$ & $42.86 \mathrm{E}$ & $6.46 \mathrm{G}$ & $31.24 \mathrm{H}-\mathrm{K}$ & $17.81 \mathrm{~A}$ & 18.36 C-E & 7.36 DE \\
\hline C.I. 2008 & $44.07 \mathrm{E}$ & $54.66 \mathrm{DE}$ & $7.42 \mathrm{FG}$ & 34.24 G-I & $17.29 \mathrm{~A}$ & 19.91 C-E & $7.64 \mathrm{DE}$ \\
\hline
\end{tabular}

${ }^{\text {a }}$ Each value is the mean of three replicates. Within a column, means followed by the same letter(s) are not significantly different $(P<0.05)$ according to Duncan's multiple range test. Determination of levels and activities of components was made when the plants were 60 days old.

Table 3. Correlation between levels and activities of some biochemical components in healthy leaves of nine flax cultivars

\begin{tabular}{|c|c|c|c|c|c|c|}
\hline \multirow{2}{*}{ Levels and activities of } & \multicolumn{6}{|c|}{ Levels and activities of } \\
\hline & Tocopherol & Phenols & MDA & Ascorbic acid & Total protein & Peroxidase \\
\hline \multicolumn{7}{|l|}{ Tocopherol } \\
\hline Phenols & $0.942 * * a$ & & & & & \\
\hline MDA & $-0.971 * *$ & $-0.895^{* *}$ & & & & \\
\hline Ascorbic acid & $0.920 * *$ & $0.983 * *$ & $-0.875^{* *}$ & & & \\
\hline Total protein & $0.943 * *$ & $0.900 * *$ & $-0.947 * *$ & $0.906^{* *}$ & & \\
\hline Peroxidase & $0.934 * *$ & $0.961 * *$ & $-0.854 * *$ & $0.961 * *$ & $0.918^{* *}$ & \\
\hline Polyphenoloxidase & $0.892 * *$ & $0.922 * *$ & $-0.853 * *$ & $0.967 * *$ & $0.901 * *$ & $0.938 * *$ \\
\hline
\end{tabular}

${ }^{a}$ Pearson's correlation coefficient $(\mathrm{r})$ is significant at $P<0.01(* *)$.

chemical components in uninfected flax leaves and PM severity were identified (Table 4 ) and the relative strength of these association was measured by calculating Pearson's

Table 4. Relationship of levels and activities of some biochemical components in uninfected leaves of nine flax cultivars and powdery mildew severity ratings on these cultivars

\begin{tabular}{lc}
\hline \hline Component & \multicolumn{1}{c}{$\mathrm{r}^{\mathrm{a}}$} \\
\hline Total protein & $-0.878^{\mathrm{b} * *}$ \\
Phenols & $-0.804^{* *}$ \\
Ascorbic acid & $-0.775^{*}$ \\
Tocopherol & $-0.847^{* *}$ \\
MDA & $0.868^{* *}$ \\
Peroxidase & $-0.783^{*}$ \\
Polyphenoloxidase & $-0.698^{*}$ \\
\hline
\end{tabular}

${ }^{a}$ Pearson's correlation coefficient, which measures the degree of association between the designated component and powdery mildew severity rating

${ }^{\mathrm{b}}$ Significant at $P<0.05(*)$ or $P<0.01(* *)$ correlation coefficient (r). However, one should keep in mind that the significant correlation does not necessarily imply causation (Gomez and Gomez, 1984). On the other hand, the causal relationships, as we have assumed herein, between the biochemical components (independent variables) and PM severity (dependent variable) are consistent with biological expectations (Göbel et al., 2003; Strange, 2003; Agrios, 2005 and Vidyasekaran, 2008).

Tocopherol and MDA, showed the highest coefficient of determination $\left(\mathrm{R}^{2}\right)$ values (Fig. 1-A and $\mathrm{C}$ ). Tocopherol was negatively correlated $(\mathrm{r}=-0.847, P<0.01)$ with $\mathrm{PM}$ severity (Table 4). It accounted for $71.78 \%$ of the total variation in PM severity (Fig. 1-A). Tocopherol prevents the oxidation of unsaturated fatty acids in cell membrane, so maintaining their structure (Daintith, 1996). Therefore, it seems reasonable to speculate that the increases in tocopherol levels in leaf tissues may enhance flax resistance to PM by protecting cell membrane from oxidative damage associated with infection.

A negative and highly significant correlation was observed between phenolics and PM severity (Table 4). Phenolics 

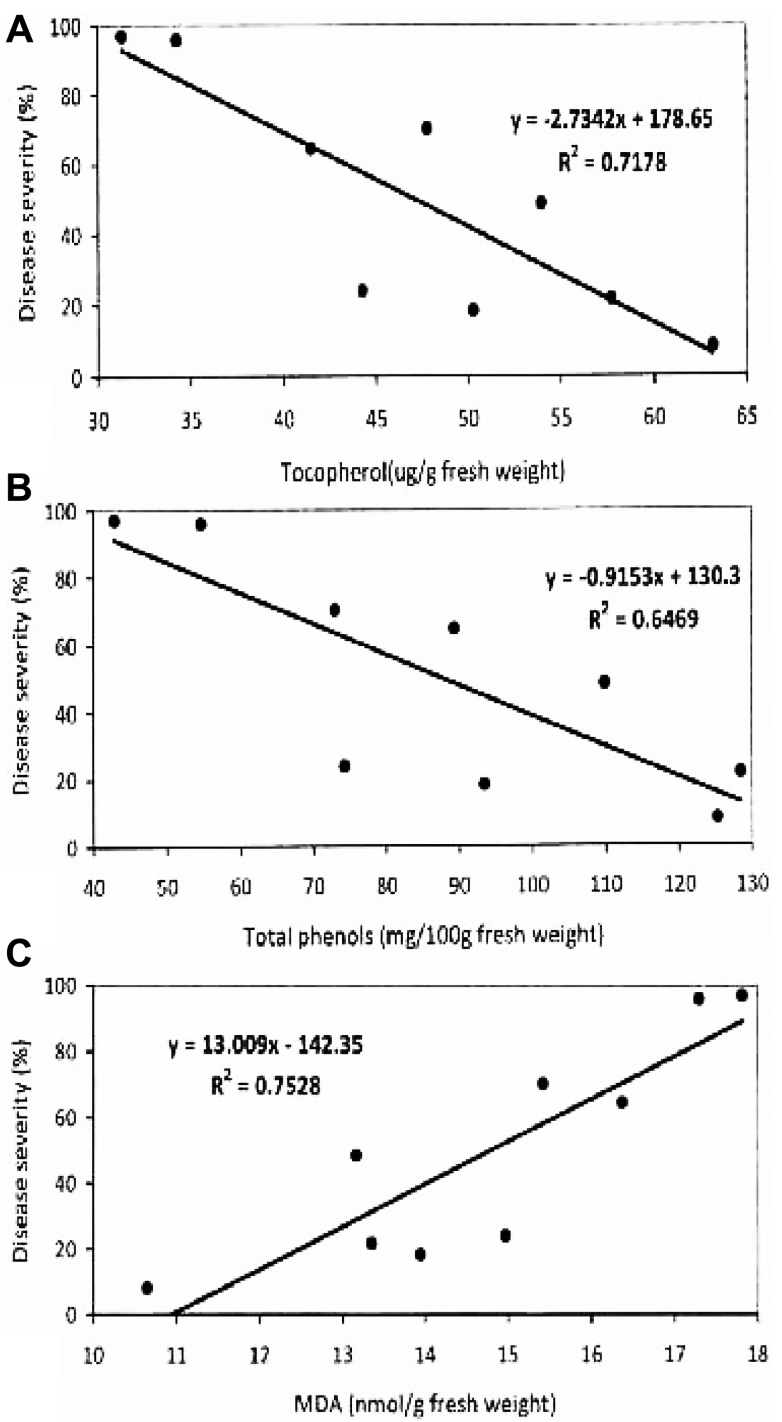

Fig. 1. Effect of (A) tocopherol, (B) phenols, and (C) malondialdehydr (MDA) content of uninfected flax leaves on powdery mildew severity.

alone accounted for $64.69 \%$ of the total variation in PM severity (Fig. 1B). It is well known that the fungitoxic effect of most phenolics is attributed mainly to their interaction with lipids or phospholipids, causing an increase in fungal membrane permeability, leakage of cell contents, and cytoplasm aggregation (Dallagnol et al., 2011). Thus, increases in the levels of pre-infectional phenolic compounds in leaf tissues may enhance flax resistance against infection by PM. The negative association between phenolics and susceptibility to PM, as we have demonstrated herein, has been supported by findings of Gawande et al. (2002), Avtar et al. (2003), Rao et al. (2007) and Satisha et al. (2008).

The MDA produced during lipid peroxidation is an indicator of cellular damage. It is well known that lipid peroxidation in the plasma membrane of cell wall by reactive oxygen species is caused by the occurrence of any type of stress to the cells (Dallagnol et al., 2011). In the present study, MDA was the only component, which showed positive correlation $(\mathrm{r}=0.868, P<0.01)$ with PM severity (Table 4). MDA accounted for $75.28 \%$ of the total variation in PM severity (Fig. 1C). This result may suggest that the preinfectional lipid peroxidation plays an important role in determining susceptibility of flax to PM. The high levels of pre-infectional lipid peroxidation, as indicated by the enhanced production of MDA, in highly susceptible cultivars (Fig. 1C), could cause an increase in flax membrane permeability that, in turn, may lead to more disease severity.

Many reports suggest that the antioxidant ascorbic acid is involved in suppression of defense genes. For example, ascorbic acid reduced the elicitor-inducible phenolic synthesis in rice (Velazhahan and Vidhyasekaran, 1999) and tomato cells (Vera-Estrella et al., 1993). Ascorbic acid inhibited the oxidation of phenolics in epicotyls of Vigna angularis (Takahama, 1993) and spinach leaves (Takahama and Oniki, 1992). It also inhibited the oxidation of coniferyl alcohol by peroxidase leads to synthesis of lignin, another important defense-related compound (Ye et al., 1990). Pastori et al. (2003) showed that many defense genes, particularly those that encode pathogenesis related-proteins were activated in Arabidopsis mutant deficient in biosynthesis of ascorbic acid. In the present study, a negative correlation was observed between ascorbic acid content and PM severity (Table 4). Ascorbic acid accounted for $60.06 \%$ of the total variation in PM severity (Fig. 2A). Our findings suggest that ascorbic acid may be involved in activation of defense genes. No conclusive biological explanation is available for the discrepancy between our findings and those reported by the others. However, one should keep in mind that there is a possibility that ascorbic acid has a dual function in inducing resistance or susceptibility depending the pathosystem under consideration.

The contribution of proteins in plant resistance to fungal infection is well documented in literature (Strange, 2003). We assessed proteins in healthy flax leaves before the appearance of any disease symptoms. Therefore, it is unlikely that any of these proteins belongs to pathogenesis-related proteins, which are induced in response to pathogen attack. It seems likely that the assessed proteins were constitutive. These groups of proteins have a role to play in plant defense through a variety of mechanisms. For instance, they may attack structural components of pathogen wall or interfere with synthesis of pathogen wall. They may also destabilize fungal membrane (Strange, 2003). Hence, the highly significant and negative correlation between total proteins and PM severity (Table 4). Total proteins also showed the highest contribution to the total variation in PM severity (Fig. 2B).

The importance of peroxidase in disease resistance stems from its property to oxidize phenolic compounds to quinones 

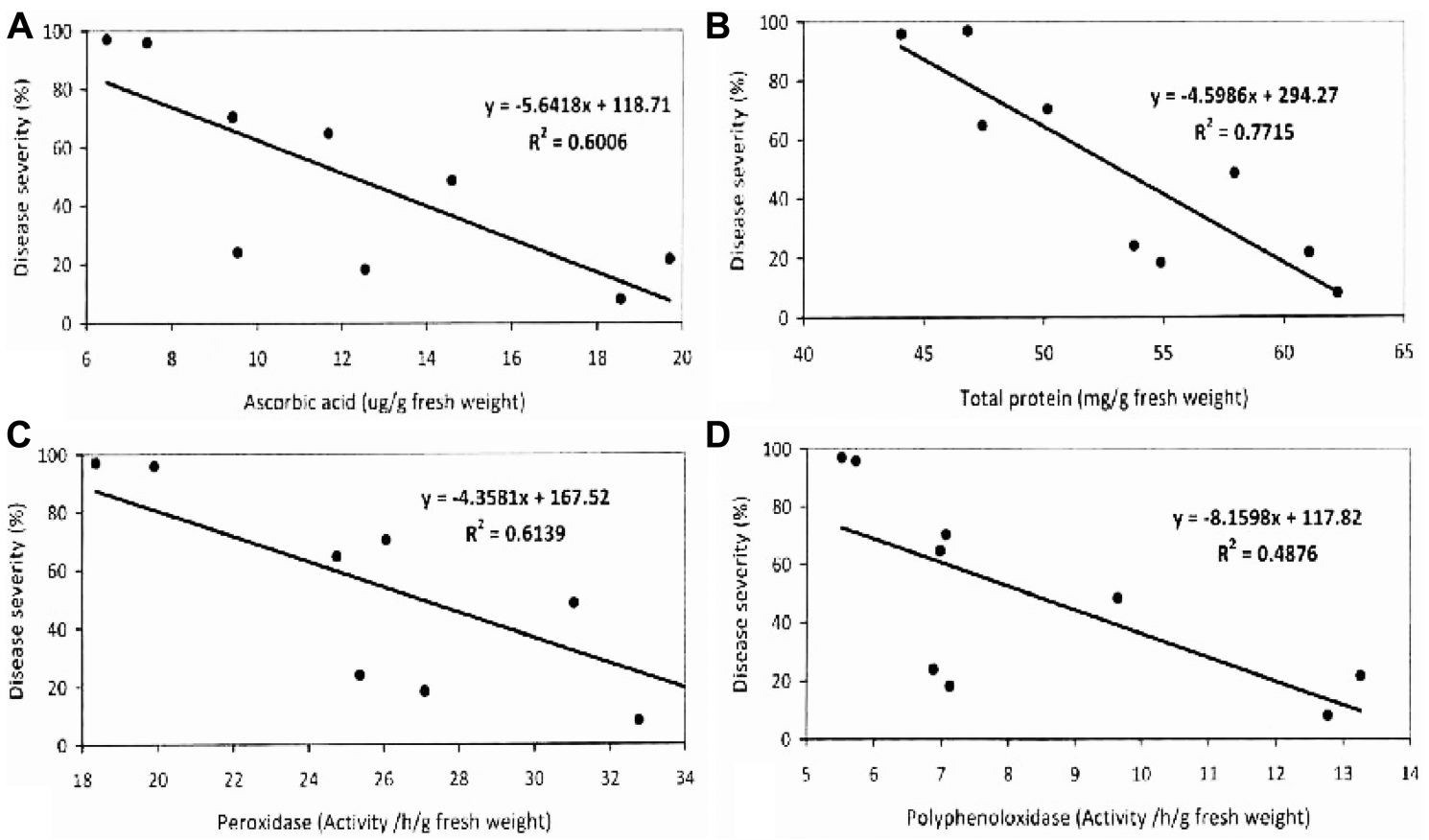

Fig. 2. Effect of (A) ascorbic acid content, (B) total protein content, (C) peroxidase activity, and (D) polyphenoloxidase activity of uninfected flax leaves on powdery mildew severity.

and semiquinones, which are often more toxic to pathogens than the original phenols. Peroxidase not only oxidizes phenolics but also increases the rate of polymerization of such compounds into lignin-like substances, which are deposited in cell walls and papillae and interfere with the further growth and development of the pathogen (Agrios, 1988). Direct antifungal effects of peroxidase on spore germination and mycelial growth have also been demonstrated (Joseph et al., 1998). Thus, it was reasonable to find a significant and negative correlation between peroxidase activity and PM severity (Table 4). Peroxidase alone accounted for $61.39 \%$ of the total variation in PM severity (Fig. 2C).

Polyphenoloxidase (PPO) is an enzyme of broad distribution among plants. Most of the reports on PPO indicate a function to defend plants against pathogens. The mode of action proposed for PPO is based on its capacity to catalyze the hydroxylation of monophenols to diphenols and their oxidation to diquinones. The quinones formed may act in several ways leading to protection of plants (Melo et al., 2006). It is worth noting that PPO showed the lowest negative correlation with PM severity (Table 4). PPO also showed the lowest contribution to the total variation in PM severity (Fig. 2D). On the other hand, contribution of phenolics to the total variation in PM severity (Fig. 1B) were much greater than that of PPO. These results suggest that flax resistance to PM may be related to the oxidative potential of phenolic composition of leaves rather than simply to a higher PPO activity (Melo et al., 2006).

Our results are in agreement with the other reports, which showed a negative association between pre-infectional activity of peroxidase and PPO and susceptibility to PM in some hosts like garden pea (Kalia, 1998), mungbean (Gawande et al., 2002), fenugreek (Avtar et al., 2003), and grapes (Roa et al., 2007).

Tocopherol, MDA, and proteins showed the highest coefficient of determination $\left(\mathrm{R}^{2}\right)$ value, that is, they were the most important contributors to the total variation in PM severity. In practical terms, the high $\mathrm{R}^{2}$ values mean that a primary selection to eliminate susceptible genotypes can be made at early stage of growth before the appearance of any visible symptoms. In this primary selection, only genotypes with high levels of tocopherol or proteins, or low levels of MDA would be retained for further evaluation under field conditions or in the greenhouse and thereby decreases the time and effort necessary for the development of resistant genotypes in breeding programs.

\section{References}

Agrios, G. N. 1988. Plant Pathology. 3rd Ed. Academic Press Inc., San Diego, California. 803 pp.

Agrios, G. N. 2005. Plant Pathology. 5th Ed. Elsevier Academic Press, San Diego, California. 384 pp.

Aly, A. A. A., Ashour, Z. A., El-Kady, E. A. F. and Mostafa, M. A. 1994. Effectiveness of fungicides for control of powdery mildew of flax and effect of the disease on yield and yield components. J. Agric. Sci. Mansoura Univ. 19: 4383-4393.

Aly, A. A., Amna, H., El-Sweify, H. and Mansour, M. T. M. 2002. 
Evaluation of some flax genotypes for powdery mildew resistance under greenhouse and field conditions. J. Agric. Sci., Mansoura Univ. 27:7323-7333.

Avtar, R., Rathi, A. S., Jatasra, D. S. and Joshi, U. N. 2003. Changes in phenolics and some oxidative enzymes in fenugreek leaves due to powdery mildew infection. Acta Phytopathol. Entomol. Hungarica 38:237-244.

Basandrai, D., Basandrai, A. K., Sethi, S. G. and Bhater, S. 1994. Evaluation of flax (Linum usitatissimum) genotypes for multiple disease resistance. Indian J. Agric. Sci. 64:704-707.

Castle, A. J. and Day, A. W. 1984. Isolation and identification of $\alpha$-tocopherol as an inducer of the parasitic phase of Ustilago violacea. Phytopathology 74:1194-1200.

Daintith, J. 1996. "A Dictionary of Chemistry". 3rd ed. Oxford University Press, Oxford. 531 pp.

Dallagnol, L. J. F. A., Rodrigues, F. M., DaMatta, M. V. B. Mielli, and Pereira, S. C. 2011. Deficiency in silicon uptake affects cytological, physiological, and biochemical events in the riceBipolaris oryzae interaction. Phytopathology 101:92-104.

Dihazi, A. D., Jaiti, F., Zouine, J., El-Hassni, M. and El-Hadrami, I. 2003. Effect of salicylic acid on phenolic compounds related to date palm resistance to Fusarium oxysporum f. sp. albedinis. Phytopathol. Medit. 42:9-16.

Gawande, V. L., Patil, J. V., Naik, R. M. and Kale, A. A. 2002. Plant biochemical defense against powdery mildew (Erysiphe polygoni DC) disease in mungbean (Vigna radiate (L.) Wilczek). J. Plant Biol. 29:337-341.

Göbel, C., Feussner, I. and Rosahl, S. 2003. Lipid peroxidation during the hypersensitive response in potato in the absence of 9-lipoxygenases. J. Biol. Chem. 278:52834-52840.

Gomez, K. A. and Gomez, A. A. 1984. Statistical Procedures for Agricultural Research. 2nd ed. John Wiley and Sons Ltd, New York. 680 pp.

Heath, R. L. and Packer, L. 1968. Photoperoxidation in isolated chloroplasts. I. Kinetics and stoichiometry of fatty acid peroxidation. Arch. Biochem. Biophys. 125:189-198.

Joseph, L. M., Koon, T. T. and Man, W. S. 1998. Antifungal effects of hydrogen peroxide and peroxidase on spore germination and mycelial growth of Pseudocercospora species. Can. J. Bot. 76:2119-2124.

Kalia, P. 1998. Enzymic association of powdery mildew resistance in garden pea. Vegetable Sci. 25:166-168.

Kar, M. and Mishra, D. 1976. Catalase, peroxidase, and polyphenoloxidase activity during leaf senescence. Plant Physiol. 57: 315-319.

Lowery, O. H., Rosembrough, N. J., Farr, A. L. and Randall, R. J. 1951. Protein measurement with the folin phenol reagent. $J$. Biol. Chem. 193:267-275.

Mahto, J. L., Choudhary, U. and Singh, S. N. 1995. Stability and genetic divergence in linseed (Linum usitatissimum) under rainfall situation. Indian J. Agric. Sci. 65:602-604.

Mansour, M. T. M., Naglaa, A. Ashry, Aly, A. A. and Zayed, S. M. E. 2003. Evaluation of some flax plant introductions for powdery mildew resistance under natural infection conditions.
J. Agric. Sci. Mansoura Univ. 28:2689-2697.

Melo, G. A., Shimizu, M. M. and Mazzafera, P. 2006. Polyphenoloxidase activity in coffee leaves and its role in resistance against the coffee leaf miner and coffee leaf rust. Phytochemistry 67:277-285.

Mukherjee, S. P. and Choudhuri, M. A. 1983. Implications of water stress induced changes in the levels of endogenous ascorbic acid and hydrogen peroxide in Vigna seedlings. Physiol. Plant. 58:166-170.

Nutter, F. W. Jr, Teng, P. S. and Shoks, F. M. 1991. Disease assessment terms and concept. Plant Dis. 75:1187-1188.

Pandy, R. N. and Misra, D. P. 1993. Assessment of yield loss due to powdery mildew of linseed. Indian Bot. Rep. 11:62-64.

Pastori, G. M., Kiddle, G., Antoniw, J., Bernard, S., VeljovicJovanovic, S., Verrier, P. J., Noctor, G. and Foyer, C. H. 2003. Leaf vitamin C. Contents modulate plant defense transcripts and regulate genes that control development through hormone signaling. Plant Cell 15:939-951.

Philip, B., Bernard, L. and William, H. 1954. Vitamins and deficiency diseases. pp. 1272-1274. In: "Practical Physiological Chemistry". McGraw-Hill Company, INC, New York.

Prasad, R., Rai, M. and Kerkhi, S. A. 1988. Resistance of linseed (Linum usitatissimum) germplasm to rust (Melampsora lini) and powdery mildew (Oidium lini). Indian J. Agric. Sci. 58: 548-549.

Rao, K. D., Jindal, P. C., Singh, R., Srivastava, G. C. and Sharma, R. C. 2007. Biochemical and genetical studies in grape germplasm for powdery mildew (Uncinula necator) disease resistance. Agric. Sci. Digest. 27:235-238.

Satisha, J., Doshi, P. and Adsula, P. G. 2008. Influence of rootstocks on changing the pattern of phenolic compounds in Thompson seedless grapes and its relationship to the incidence of powdery mildew. Turkish. J. Agric. Fores. 32:1-9.

Strange, R. N. 2003. "Introduction to Plant Pathology". John Wiley and Sons Ltd, West Sussex, England. $480 \mathrm{pp}$.

Takahama, U. and Oniki, T. 1992. Regulation of peroxidasedependent oxidation of phenolics in the apoplast of spinach leaves by ascorbate. Plant Cell Physiol. 33:379-387.

Velazhahan, R. and Vidhyasekaran, P. 1999. An elicitor of the rice sheath blight pathogen Rhizoctonia solani exhibits dual function: elicitation and suppression of tissue necrotization in rice. Acta Phytopathol. Entomol. Hungarica 34:187-198.

Vera-Estrella, R., Blumwald, E. and Higgins, V. J. 1993. Non-specific glycopeptides elicitor of Cladosporium fulvum: evidence for involvement of active oxygen species in elicitor-induced effects on tomato cell suspensions. Physiol. Mol. Plant Pathol. 42:9-22.

Vidhyasekaran, P. 2008. "Fungal Pathogenesis in Plants and Crops: Molecular Biology and Host Defense Mechanisms" 2nd ed., CRC Press, Boca Raton, Florida. 509 pp.

Ye, X. S., Pan, S. Q. and Kuc, J. 1990. Activity, isozyme pattern, and cellular localization of peroxidase as related to systemic resistance of tobacco to blue mold (Peronospora tabacina) and to tobacco mosaic virus. Phytopathology 80:1295-1299. 